\title{
Prostatic Artery Embolization in Benign Prostatic Hyperplasia Patients with High Comorbidity
}

\section{Benign Prostat Hiperplazisi Olan Komorbiditesi Yüksek Hasta Grubunda Prostat Arter embolizasyonu}

\author{
Çağlayan Çakır ${ }^{1 \oplus}$, Aysun Erbahceci Salik ${ }^{1 \oplus}$, Fatih Kılınç $^{1 \oplus}$, Filiz Saçan ${ }^{2 \oplus}$, Levent Oguzkurt ${ }^{3 \oplus}$, Volkan Tugcu ${ }^{4} \oplus$ \\ ${ }^{1}$ Health Science University, Bakirkoy Dr Sadi Konuk Education and Research Hospital, Department of Radiology, Istanbul, Turkey \\ ${ }^{2}$ Acıbadem Education and Research Hospital, Department of Radiology, Istanbul, Turkey \\ ${ }^{3}$ Koç University Hospital, Department of Radiology, Istanbul, Turkey \\ ${ }^{4}$ Memorial Hospital, Department of Urology, Istanbul, Turkey
}

Received: 24.03.2020 / Accepted: 30.03.2021 / Published Online: 31.03.2021

Cite as: Çakır Ç, Erbahceci Salik A, Kılınç F, Saçan F, Oguzkurt L, Tugcu V. Prostatic artery embolization in benign prostatic hyperplasia patients with high comorbidity. Med J Bakirkoy 2021;17(1):79-84.

\begin{abstract}
Objective: Benign prostatic hyperplasia (BPH) affects patients' quality of life negatively. We aimed to examine the results of prostate artery embolization (PAE) treatment for BPH in the elderly patients with high comorbidity.

Materials and Methods: In the present study, we evaluated the patients with lower urinary tract symptoms (LUTS) due to BPH and applied endovascular embolization treatment, who were admitted to our hospital radiology department, between February 2017 and February 2019. Patients with a high risk for surgical operation with an American Society of Anesthesiologists (ASA) score of 3 or above, International Prostate Symptom Score (IPSS) $>20$ and MR (Magnetic Resonance) prostate volume (PV) $>70 \mathrm{~cm} 3$ were included in this study. In addition, maximum flow rate Qmaximum (Qmax), MRI PV and IPSS values were recorded in all patients in our clinic before PAE, and the 12th months after PAE. Results: In our study, 15 patients, who had a history of transurethral resection (TUR), and 57-82 years old (mean 73.8), participated. PAE treatment was administered to the patients who were admitted to our hospital with the diagnosis of BPH in patient high comorbidity, LUTS and high risk for open prostatectomy. In our series, Qmax, IPSS, MRI and digital subtraction angiography (DSA) findings were presented. The

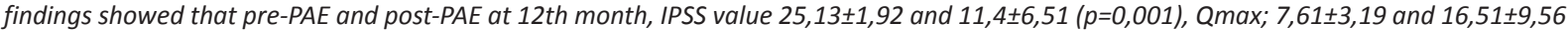
$(p=0,001), M R P V ; 135,47 \pm 76,48$ and $83,27 \pm 43,53(p=0,001)$ and also all parameters were statistically significant.

Conclusion: PAE is a novel treatment modality which is increasingly being used in patients with BPH, and it is an important and effective treatment option since it is much less invasive compared to open surgery, does not require hospitalization after the procedure.
\end{abstract}

Keywords: Benign prostatic hyperplasia, prostate artery, embolization, high comorbidity

Öz

Amaç: Benign prostat hiperplazisi (BPH) yaşam kaltisini olumsuz etkileyen bir durumdur. Çalışmamızda BPH tanılı ve komorbitesi yüksek yaşlı hastalarda Prostat arter embolizasyonu tedavisinin sonuçlarını gözden geçirmeyi amaçladık.

Yöntem: Şubat 2017-Şubat 2019 tarihleri arasında hastanemize Benign Prostat Hiperplazisine (BPH) bağlı alt üriner sistem semptomları (AÜSS) nedeniyle bașvurup prostat arter embolizasyon (PAE) tedavi işlemi uygulanan hastaları retrospektif olarak inceledik. Çalışmaya Amerikan Anestezistler Derneği (ASA) skoru 3 ve üzerinde olan cerrahi operasyon açısından yüksek riskli, Uluslararası Prostat Semptom Skoru (IPSS) >20, MR (Manyetik Rezonans) ile prostat volümü (PV) $>70 \mathrm{~cm} 3$ olan hastalar dahil edildi. Bunun dışında hastalarda PAE öncesi ve PAE sonrası 12. ayda, maksimum akım hızı Qmaksimum (Qmaks), MRG PV ile IPSS değerleri kaydedildi.

Bulgular: Çalıșmamızda komorbitesi yüksek, alt üriner sistem semptomları devam eden ve açık prostatektomi için yüksek riskli $57-82$ yaș arası (ort. 73,8) daha önce bir tanesi transüretral rezeksiyon (TUR) operasyonu geçirmiş olmak üzere toplam on beş hastaya prostat arter embolizasyon (PAE) işlemi yapıldı. Serimizde hastaların Qmaks, iPSS, MR ve dijital subtraksiyon anjiyografi (DSA) bulguları sunulmuștur. PAE

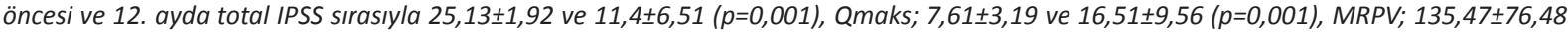
ve $83,27 \pm 43,53(p=0,001)$ olup değerleri kayıt altına alındı.

Sonuç: PAE BPH olan hastalarda giderek artar sıklıkta kullanılmakta olan yeni bir tedavi yöntemi olup özellikle komorbiditesi yüksek grupda TUR ile açık cerrahiye göre çok daha az invaziv olması, işlem sonrası hastanede yatış gerektirmemesi ve basit sedasyon ya da lokal anestezi altında yapılabilir olması ile önemli alternatif bir seçenektir.

Anahtar kelimeler: Benign Prostat Hiperplazisine, Embolizasyon, Prostat Arter, Yüksek komorbidite

\begin{tabular}{lrrr}
\hline Corresponding Author: & Ç. Çakır 0000-0001-8030-6795 & F. Kilınç 0000-0002-7224-7737 & L. Oguzkurt 0000-0001-7744-9103 \\
drcakir1983@gmail.com & A. Erbahceci Salik 0000-0001-5344-560X & F. Saçan 0000-0001-6498-9549 & V. Tugcu 0000-0002-4136-7584
\end{tabular}




\section{INTRODUCTION}

In the high comorbidity patient group, endovascular embolization is a significant alternative life-saving treatment method. Benign prostatic hyperplasia $(\mathrm{BPH})$ is a condition that occurs with advancing age. Although BPH does not pose a vital threat, it reduces the quality of life of the patient due to the symptoms patients encountered. Lower urinary tract complaints (LUTS) occur because of many reasons and one of the most common and most important causes is $\mathrm{BPH}$. BPH-related LUTS occur as storage and micturition complaints. The complaints regarding LUTS are defined frequency, urgency, nocturia, straining, weak stream, intermittency, hesitancy and incomplete emptying. These BPH-related complaints occur in approximately $30 \%$ of men older than 65 years of age, which are due to increased prostate volume and increased prostatic smooth muscle tone or bladder neck failure in theory. The aim of the treatment is to prevent complications due to $\mathrm{BPH}$ and to improve the quality of life of the patient. Although medical treatment is beneficial to many patients, transurethral resection (TUR) is the gold standard treatment for $\mathrm{BPH}$ in patients. In TUR, prostate volume is important and it has been shown to be effective in prostates between 30 and $80 \mathrm{~cm} 3$ and open prostatectomy is preferred in larger prostates. However, especially in open prostatectomy, TUR and other treatment methods carry serious risks in patients with high comorbidity ${ }^{(1)}$. PAE, which is a minimally invasive method, can be performed by intravenous sedation or local anesthesia. Many studies have shown that PAE is becoming an important option in reducing prostate gland volume by relieving lower urinary tract symptoms and improving the quality of life of patients $(2,3)$. BPH affects patients' quality of life negatively. In the high comorbidity patient group, PAE is an important alternative treatment method by experienced interventional radiologists angiographyguided.

\section{MATERIALS AND METHODS}

We obtained informed consent forms from all patients for the PAE procedure. Before the procedure, IPSS system scoring was used in all patients worldwide. IPSS is an evaluation method that helps to find out the degree of obstruction based on the
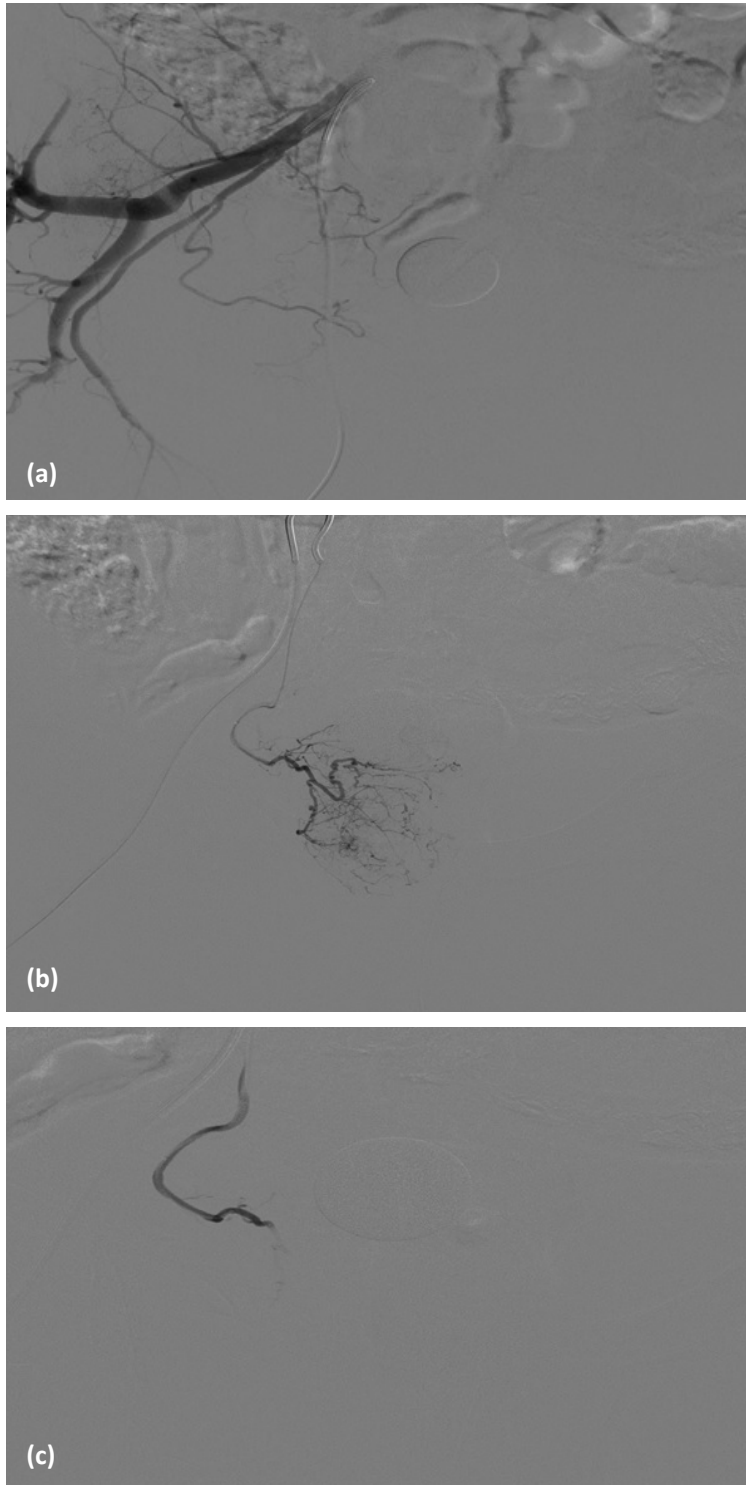

Figure 1. Digital subtraction angiography showing (a) Origin of the prostate artery (PA) from the internal pudendal artery, (b) Selective probing and visualization of the distal prostate artery with contrast enhancement of the prostate parenchyma and last image (c) after successful embolization of the prostate artery.

complaints of the prostate enlargement, gives healthy results, especially in moderate and severe obstructions in scientific studies. Score and symptoms are evaluated as mild in 0-7, moderate in 8-19, and severe in 20-35.

In this study, patients with high risk for surgical operation with an American Society of Anesthesiologists (ASA) score of 3 or above, International Prostate Symptom Score (IPSS) >20 and MR (Magnetic Resonance) prostate volume (PV)>70 $\mathrm{cm} 3$ were included. 

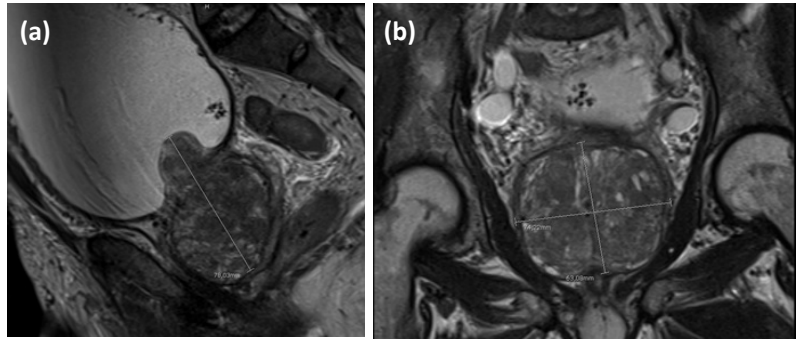

Figure 2. In this case, T2-weighted pelvic MRI in sagittal and coronal views before $(a, b)$ and after (c, d ) PAE. Note the significant volumetric reduction of the prostatic central gland. T1-weighted contrast axial image (e) with left infarcted areas in the central gland after PAE (White arrow).

MRI was performed using a 3-Tesla whole-body MRI (Siemens Verio, Malvern, PA, U.S.) and a pelvic phased-array surface coil. T2-weighted images were obtained in the axial, sagittal, and coronal planes. MRI features of the included patients, their prostate MRI reads-pirads scores 1 and 2, their volume was measured-ellipsoid formula (height $\times$ width $\times$ length $\times \pi / 6)$ and who processed this data with two radiologist ten years of experience.

All patient received medical treatment (alpha-2 blockers) prior to PAE. All the patients underwent prostate biopsy before the procedure and negative ones were included in this study. Patients with neurogenic bladder disorders or elevated creatinine levels and patients who were malignant as a result of transrectal ultrasound guided prostate biopsy were excluded from this study. In addition, maximum flow rate Qmaximum (Qmax), MRI PV, IPSS values and digital subtraction angiography (DSA) images were reviewed from the patient file, computer registry system and imaging archives retrospectively. They were recorded in all patients in our clinic before PAE, in 12th months after PAE.

Presence of urine specimens and cultures and accompanying infection were excluded in patients using chronic catheters. All patients were administered $500 \mathrm{mg}$ ciprofloxacin, non-steroidal anti-inflammatory drug and proton pump inhibitor on the day before the procedure. Foley catheter was inserted in all patients before the procedure, and the foley catheter was filled with $3 / 4$ iodine contrast material and 1/4 saline solution. In addition, IV hydration was applied during procedure to ensure the elimination for a contrast agent.
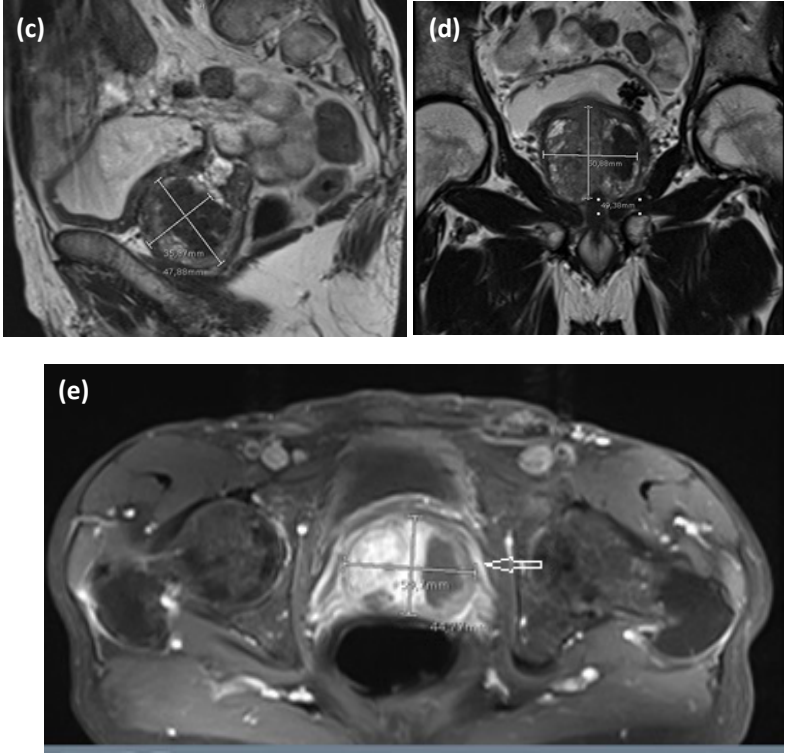

Afterwards UAE procedures were performed under fluoroscopic (Allura FD 20/20, PhilipsMedicalSystem, Best, Netherlands) in the interventional treatment unit of our hospital. An ultrasound-guided $5 \mathrm{Fr}$ arterial sheath was placed on the right CFA in the procedure. Subsequently, the diagnostic catheter was selectively catheterized left internal iliac artery by using the cobra catheter ( $5 \mathrm{Fr}$ ) [Cordis, Corporation, Bridgewater, NJ, USA]. And then diagnostic catheter was selectively catheterized right internal iliac artery by using the simmon 1 cathater (5 Fr) [Cordis, Corporation, Bridgewater, NJ, USA]. Subsequently, super selectively catheterized bilateral prostate artery artery by using the a high-flow microcatheter. Particle embolization was performed with 100-300 micron and 300-500 micron particles. In the control angiographies; we performed complete embolization was achieved after embolization (Figure 1). There were no complications associated with endovascular procedure.

Immediately after the procedure, the foley catheter was removed and all patients were administered peroral $500 \mathrm{mg}$ ciprofloxacin, non-steroid antiinflammatory drug and proton pump inhibitor twice daily for 10 days.

\section{STATISTICAL ANALYSIS}

Frequency and percentage values were given for categorical variables. Mean, standard deviation, median, minimum and maximum values were given 
Table 1.

\begin{tabular}{|c|c|c|c|}
\hline & Pre PAE & Post PAE & \\
\hline & $\begin{array}{c}(\mathbf{n}) \\
\text { Mean+Standart } \\
\text { Deviation } \\
\text { Med. (Min.- } \\
\text { Max.) }\end{array}$ & $\begin{array}{c}(\mathbf{n}) \\
\text { Mean+Standart } \\
\text { Deviation } \\
\text { Med. (Min.- } \\
\text { Max.) }\end{array}$ & $\mathbf{p}$ \\
\hline MRG & $\begin{array}{c}(n=15) \\
135,47 \pm 76,48 \\
93-(55-345)\end{array}$ & $\begin{array}{c}(n=15) \\
83,27 \pm 43,53 \\
80-(35-175)\end{array}$ & 0,001 \\
\hline QMAX & $\begin{array}{c}(n=15) \\
7,61 \pm 3,19 \\
6,6-(5-17)\end{array}$ & $\begin{array}{c}(n=15) \\
16,51 \pm 9,56 \\
12-(8,8-39,9)\end{array}$ & 0,001 \\
\hline iPSS & $\begin{array}{c}(n=15) \\
25,13 \pm 1,92 \\
24-(23-29)\end{array}$ & $\begin{array}{c}(n=15) \\
11,4 \pm 6,51 \\
12-(3-19)\end{array}$ & 0,001 \\
\hline $\begin{array}{l}\text { Wilcoxon sign } \\
\text { sorts test }\end{array}$ & & & \\
\hline
\end{tabular}

for continuous variables. The normal distribution of continuous variables was tested by the Kolmogorov Smirnov test. Mann-Whitney $U$ test was used for comparison of two independent groups and KruskalWallis $\mathrm{H}$ test was used for comparisons of more than two groups. Independent variables that could not show normal distribution, Wilcox's sign rank test was used for comparisons between two groups. A value of $p<0.05$ was considered statistically significant. Statistical analyses of the data obtained in the study were performed using NCSS 11 software (Number Cruncher Statistical System, 2017 Statistical Software).

\section{RESULTS}

In our study, a total of 15 patients involved, who were $57-82$ years old (mean 73.8 ) and had a history of TUR. PAE treatment was performed on the patients who were admitted to our hospital with the diagnosis of BPH, high comorbidity, lower urinary tract symptoms and high risk for open prostatectomy. In our series, Qmax, IPSS, MRI and digital subtraction angiography (DSA) findings were presented. The findings showed that pre- PAE and post-PAE at 12th month, IPSS value $25,13 \pm 1,92$ and $11,4 \pm 6,51$ $(p=0,001), \quad Q \max ; 7,61 \pm 3,19$ and $16,51 \pm 9,56$ $(p=0,001), M R P V ; 135,47 \pm 76,48$ and $83,27 \pm 43,53$ $(p=0,001)$ and all parameters were statistically significant. MRI $(p=0.001, p<0.05)$, according to the pre-median post-value, $\mathrm{Qmax}(\mathrm{p}=0.001, \mathrm{p}<0.05)$ according to the pre-median value of the postmedian value, IPSS ( $p=0.001, p<0,05)$ pre-median value was significantly higher than post-median value. (Table 1) Embolization was performed unilaterally due to intense atherosclerotic causes in two patients and cardiac reasons developed during angiography in one patient. The other 12 patients underwent successful PAE procedure bilaterally. Twelve patients $(12 / 15, \% 80)$ were discharged on the same day following bed rest with significant reduction in urinary retention. Two patients could be discharged 1 week later due to cardiac extra problems during the procedure and one patient developed urosepsis. All patients underwent clinical examination both before and 3, 6, 12 months after PAE. The average follow-up period for all the patients was 20 months (14-26). BPH is a long process to treat and follow up with possible rebounds and our follow up plans, ultrasonography in the methods section.

\section{DISCUSSION}

$\mathrm{BPH}$ is seen with increasing frequency in men with age. BPH is detected in more than $90 \%$ of men over 80 years of age and causing LUTS in more than 50\% of these patients. Medical treatment and minimally invasive surgical techniques have become more prominent in the treatment of BPH with increasing life expectancy worldwide. Currently, TUR is the gold standard treatment for $\mathrm{BPH}$ of the prostate gland and if the prostate volume exceeds $80 \mathrm{~cm} 3$, choice open prostatectomy for treatment. However, as in our series, other treatments, especially open prostatectomy, have serious risks for patients with high comorbidity. Especially minimally invasive treatments, such as PAE on the positive effects of LUTS, it has been increasingly used due to the better quality of life of patients compared to TUR and prostatectomy treatment.

PAE as an alternative treatment option for BPH and it was first described in detail by DeMeritt et al ${ }^{(4)}$. PAE requires minimal anesthesia, and patients can return to their daily lives in a day or several days similar to other minimally invasive treatment methods, which makes us more advantageous and advantageous than the surgical methods in patients with additional comorbidities ${ }^{(4,5)}$. However, PAE should be performed 
by experienced vascular interventional radiologists because of secondary changes in atherosclerosis in these elderly patients. The aim with PAE is to prevent the blood supply of the central and peripheral sections by occluding the small precapillary arterioles that feed the prostate gland using the ideal sized embolizing agent ${ }^{(6)}$. Embolic agents used today; Non-spheric polyvinyl alcohol (PVA) particles, trisacryl gelatin microspheres and Embozene microspheres have been shown to be successful and safe in reducing prostate gland and LUTS. ${ }^{(7)}$ In an animal experiment study on dogs using Embosphere microspheres, $300-500 \mu \mathrm{m}$ and $500-700 \mu \mathrm{m}$ particles were shown to cause more parenchymal destruction based on MRI results. (8) In another series, we published mid-term results by comparing 50 and 100 particles with other 300-500 $\mu \mathrm{m}$ trisacryl microspheres, they found no statistically significant difference in clinical and urodynamic results compared in prostates $>80 \mathrm{~g} .{ }^{(9,10,11)}$.

Although all these studies show that there is no consensus on the particle size in the literature, when the sizes in the range of 100-300 micron and 300500 micron particles are used as in our series, the distribution of the particles is homogeneous ${ }^{(12,13)}$. In addition, off-target embolization should be carefully avoided by preserving the vesical, rectal and penile artery branches during the procedure.

Using 300-500 $\mu \mathrm{m}$ trisacryl microspheres, Carnevale et al. ${ }^{(14)}$ showed that PV decreased more in PAE and there was no significant difference between PAE and TUR in the decrease of IPSS score in both TUR and PAE, but TUR was more effective for Qmax values in a study. In another study, 11 patients with BPHinduced urinary retention after PAE had a 2.8-point decrease in IPSS $(p=0.04)$ as a result of one-year follow-up in one study, and Qmax from 4.2 to $10.8 \mathrm{ml}$ / sec. $(p=0.009)$. ${ }^{(15)}$ In a study, 22 patients with TURP and prostatectomy could not be performed mean comorbidity of $73.86 \pm 6.25$ years, total PSA, Qmax, TPV, IPSS and TPV were evaluated and the positive effect of PAE on these parameters was emphasized. (16) In our study, patients with high comorbidity, lower urinary tract symptoms and high risk of operation for open prostatectomy and TURP were included. Carnavale et al. ${ }^{(14)}$ compared PAE with TURP and the technique developed by him, and a statistically significant improvement in IPSS score, prostate volume, and Qmax were detected in all three groups. However, while the improvement in Qmax and the decrease in prostate volume were higher in the TURP group, IPSS scores were lower in the TURP and PAE group developed by the technique than the original PAE group. However, the need for spinal anesthesia and hospitalization for TURP and more side effects should be kept in mind. Open prostatectomy is the gold standard treatment method for prostates with a volume greater than 80 $\mathrm{cm} 3$, but the rate of surgical complications increases, especially as the prostate volume increases $(17,18)$. However, there is currently no upper limit for prostate volume in the treatment of PAE. ${ }^{(9,19)}$ Moreover, because of the high morbidity rate of open prostatectomy, causing a high amount of bleeding during surgery and a new less invasive method, PAE has come to the for requiring intensive care after the procedure. In another studies, PAE is a safe and minimally invasive method to treatment of $\mathrm{BPH}$ in patients ${ }^{(20,21,22)}$.

PAE is not an obstacle to surgery and patients with no significant response to urodynamic parameters after PAE devastate the prostate gland and thus minimizing the bleeding complication during the surgery. Although PAE is a technically difficult procedure, it has been applied to thousands of patients in the world as of 2019. An important limitation of our study was the small number of patients, and the most important reason for this was that urology clinics approach this minimally invasive method with caution due to the low awareness of PAE method and its efficacy in our country. As in our series, it is a safe and effective treatment method, but if it is applied by experienced centers because of difficulties due to atherosclerosis and variations in pelvic vascular anatomy in elderly patients. PAE is a novel treatment modality which is increasingly being used in patients with BPH, and it is an important and effective treatment option since it is much less invasive compared to open surgery, does not require hospitalization after the procedure. 
Ethics Committee Approval: Non-Invasive Research Ethics Committee approval was obtained from Bakirkoy Dr. Sadi Konuk Training and Research Hospital (22.07.2019/2019-14-04).

Conflict of Interest: The authors have no conflict of interest and also declare that no funding was received for the conduct of this study. Informed Consent: All participants signed an informed consent form before participating in the study.

\section{REFERENCES}

1. Oelke M, Bachmann A, Descazeaud A et al. EAU guidelines on the treatment and follow-up of non-neurogenic male lower urinary tract symptoms including benign prostatic obstruction. EurUrol. 2013;64:118-40. https://doi.org/10.1016/j.eururo.2013.03.004

2. Pisco J, Campos Pinheiro L, Bilhim T et al. Prostatic arterial embolization for benign prostatic hyperplasia: shortand intermediateterm results. Radiology 2013;266:668-77. https://doi.org/10.1148/radiol.12111601

3. Carnevale FC, Moreira AM, Antunes AA. The "PErFecTED technique": proximal embolization first, then embolize distal for benign prostatic hyperplasia. Cardiovasc Intervent Radiol 2014;37:1602-5 https://doi.org/10.1007/s00270-014-0908-z

4. DeMeritt JS, Elmasri FF, Esposito MP et al. Relief of benign prostatic hyperplasia-related bladder outlet obstruction after transarterial polyvinyl alcohol prostate embolization. J Vasc IntervRadiol 2000;11:767-70. https://doi.org/10.1016/S1051-0443(07)61638-8

5. Mirakhur A, McWilliams JP. Prostate Artery Embolization for Benign Prostatic Hyperplasia: Current Status. Can Assoc Radiol J 2017;68:84-9. https://doi.org/10.1016/j.carj.2016.06.003

6. Sun F, Crisóstomo V, Báez-Díaz C et al. Prostatic Artery Embolization (PAE) for Symptomatic Benign Prostatic Hyperplasia (BPH): part 2, insights into the technical rationale. Cardiovasc Intervent Radiol 2016;39:161-9. https://doi.org/10.1007/s00270-015-1238-5

7. Bagla S, Martin CP, van Breda A et al. Early results froma United States trial of prostatic artery embolization in the treatment of benign prostatic hyperplasia. JVasc Interv Radiol 2014;25:47-52. https://doi.org/10.1016/j.jvir.2013.09.010

8. Brook OR, Faintuch S, Brook A et al. Embolization therapy for benign prostatic hyperplasia: influence of embolization particle size on gland perfusion. J Magn Reson Imaging 2013;38:380-7. https://doi.org/10.1002/jmri.23981

9. de Assis AM, Moreira AM, de Paula Rodrigues VC et al. Prostatic artery embolization for treatment of benign prostatic hyperplasia in patients with prostates $90 \mathrm{~g}$ :a prospective single center study. J Vasc Interv Radiol 2015;26:87-93. https://doi.org/10.1016/j.jvir.2014.10.012
10. Kurbatov D, Russo Gl, Lepetukhin A et al. Prostatic artery embolization for prostate volume greater than $80 \mathrm{~cm} 3$ : results from a single center prospective study. Urology 2014;84:400-4. https://doi.org/10.1016/j.urology.2014.04.028

11. Wang M, Guo L, Duan F et al. Prostatic arterial embolization for the treatment of lower urinary tract symptoms caused by benign prostatic hyperplasia: a comparative study of medium-and largevolume prostates. BJU International 2016;117:155-64. https://doi.org/10.1111/bju.13147

12. Carnevale FC, Antunes AA. Prostatic artery embolization for enlarged prostates due to benign prostatic hyperplasia. How I do it. Cardiovasc Intervent Radiol 2013;36:1452-63. https://doi.org/10.1007/s00270-013-0680-5

13. Pisco JM, Pereira J, Tinto HR et al. How to perform prostatic arterial embolization. Tech Vasc Interventional Radiol 2012;15:286-9. https://doi.org/10.1053/j.tvir.2012.09.002

14. Carnevale FC, Iscaife A, Yoshinaga EM et al. Transurethral resection of the prostate TURP) versus original and PErFecTED prostate artery embolization (PAE) due to benign prostatic hyperplasia $(\mathrm{BPH})$ : preliminary results of a single center, prospective, urodynamic-controlled analysis. Cardiovasc Intervent Radiol 2016;39:44-52. https://doi.org/10.1007/s00270-015-1202-4

15. Antunes AA, Carnevale FC, da Motta Leal Filho JM et al. Clinical, laboratorial, and urodynamic fndings of prostatic artery embolization for the treatment of urinary retention related to benign prostatic hyperplasia. A prospective single-center pilot study. Cardiovasc Intervent Radiol 2013;36:978-86. https://doi.org/10.1007/s00270-013-0611-5

16. Yıldırım iO, Duman E, Fırat A et al. Evaluation of Prostatic Artery Embolization Efficiency in Benign Prostatic Hyperplasia Patients with High Comorbidity. Bull Urooncol 2018;17:14-17. https://doi.org/10.4274/uob.937

17. Seki N, Naito S. Instrumental treatments for benign prostatic obstruction. Curr Opin Urol 2007;17:17-21. https://doi.org/10.1097/MOU.0b013e32800ff766

18. Rassweiler J, Teber D, Kuntz R. Complications oftransurethral resection of the prostate (TURP)-incidence, management, and prevention. Eur Urol 2006;50:969-79. https://doi.org/10.1016/j.eururo.2005.12.042

19. Wang MQ, Guo LP, Zhang GD et al. Prostatic arterial embolization for the treatment of lower urinary tract symptoms due to large $(80 \mathrm{~mL})$ benign prostatic hyperplasia: results of mid-term follow- up from Chinese population. BMC Urol 2015 Apr;15:33. https://doi.org/10.1186/s12894-015-0026-5

20. Insausti I, Sáez de Ocáriz A, Galbete A et al. Randomized Comparison of Prostatic Artery Embolization versus Transurethral Resection of the Prostate for Treatment of Benign Prostatic Hyperplasia. J Vasc Interv Radiol. 2020 Jun;31(6):882-90. https://doi.org/10.1016/j.jvir.2019.12.810

21. Lin YT, Pereira H, Pellerin O et al. Four-Year Impact of Voiding and Storage Symptoms in Patients with Benign Prostatic Hyperplasia Treated with Prostatic Artery Embolization. J Vasc Interv Radiol. 2020 Sep;31(9):1460-6. https://doi.org/10.1016/j.jvir.2019.08.034

22. Xu XJ, Li J, Huang XZ et al. An updated meta-analysis of prostatic arterial embolization versus transurethral resection of the prostate in the treatment of benign prostatic hyperplasia.World J Urol. 2019;38:2455-68.

https://doi.org/10.1007/s00345-019-03044-7 